NBER WORKING PAPER SERIES

\title{
PRUDENTIAL SUPERVISION: WHY IS IT IMPORTANT AND WHAT ARE THE ISSUES?
}

Frederic S. Mishkin

Working Paper 7926

http://www.nber.org/papers/w7926

\author{
NATIONAL BUREAU OF ECONOMIC RESEARCH \\ 1050 Massachusetts Avenue \\ Cambridge, MA 02138 \\ September 2000
}

Prepared for the NBER conference, "Prudential Supervision: What Works and What Doesn't," held at Cheeca Lodge, Islamorada, Florida, January 13-15, 2000. I would like to thank Allen Berger, Mark Carey, Mark Flannery, Patricia Jackson, Randall Kroszner and other participants at the conference for their helpful comments. Any views expressed in this paper are those of the author only and not those of Columbia University or the National Bureau of Economic Research. The views expressed are those of the author and not necessarily those of the National Bureau of Economic Research.

(C) 2000 by Frederic S. Mishkin. All rights reserved. Short sections of text, not to exceed two paragraphs, may be quoted without explicit permission provided that full credit, including (C) notice, is given to the source. 
Prudential Supervision: Why Is It Important and What are the Issues?

Frederic S. Mishkin

NBER Working Paper No. 7926

September 2000

JEL No. G21

ABSTRACT

This paper outlines what problems asymmetric information creates for the financial system and shows and shows that the presence of asymmetric information explains why banks are so important. The paper then goes on to explain why prudential supervision of these institutions is needed, and what forms it takes. The paper ends by outlining the key issues in the design of prudential supervision and uses them to organize a general discussion of the papers in this conference volume, providing a brief overview of their content. The linkages between these papers are explored, which highlights some general conclusions.

Frederic S. Mishkin

Uris Hall 619

Graduate School of Business

Columbia University

New York, New York 10027

and NBER

fsm3@columbia.edu 


\section{1. \\ Introduction}

Prudential supervision, broadly construed, involves government regulation and monitoring of the banking system to ensure its safety and soundness. This conference volume contains papers which examine prudential supervision, what works and what doesn't. To understand the importance of this topic, it is worth taking a step back and examining more basic questions: why is prudential supervision so important, why does it take the form it does. This chapter provides an introduction to this volume by doing exactly this.

To understand why getting prudential supervision right is so crucial to the efficient functioning of the financial system, first we need to know how asymmetric information plays a key role in the way the financial system operates. This chapter first outlines what problems asymmetric information creates for the financial system and shows that the presence of asymmetric information explains why banks are so important. The chapter then goes on to explain why prudential supervision of these institutions is needed, and what forms it takes.

The chapter ends by outlining the key issues in the design of prudential supervision and uses them to organize a general discussion of the papers in this volume, providing a brief overview of their content. The linkages between these papers are explored, which highlights some general conclusions.

\section{2. \\ The Role of Asymmetric Information in the Financial System}

The financial system is critical to the health of the economy because it performs the essential function in an economy of channeling funds from savings to those individuals or firms that have productive investment opportunities. If the financial system does not perform this

role well, then the economy cannot operate efficiently and economic growth will be severely hampered. A crucial impediment to the efficient functioning of the financial system is 
asymmetric information, a situation in which one party to a financial contract has much less accurate information than the other party. For example, borrowers who take out loans usually have much better information about the potential returns and risk associated with the investment projects they plan to undertake than lenders do. Asymmetric information leads to two basic problems in the financial system: adverse selection and moral hazard.

Adverse selection is an asymmetric information problem that occurs before the transaction occurs because lower quality borrowers with higher credit risk are the ones who are most willing to take out a loan or pay the highest interest rate. Thus, the parties who are the most likely to produce an undesirable (adverse) outcome are most likely to be selected. For example, those who are poor credit risks are likely to be the most eager to take out a loan and pay a high interest rate because they know that they are unlikely to pay it back. Since adverse selection makes it more likely that loans might be made to bad credit risks, lenders may decide not to make any loans even though there are good credit risks in the marketplace. This outcome is a feature of the classic "lemons problem" analysis first described by Akerlof(1970). Clearly, minimizing the adverse selection problem requires that lenders must screen out good from bad credit risks.

Moral hazard occurs after the transaction takes place because the lender is subjected to the hazard that the borrower has incentives to engage in activities that are undesirable from the lender's point of view: i.e., activities that make it less likely that the loan will be paid back. Moral hazard occurs because a borrower has incentives to shift into projects with high risk in which the borrower does well if the project succeeds but the lender bears most of the loss if the project fails. Also the borrower has incentives to misallocate funds for her own personal use, to shirk and just not work very hard, or to undertake investment in unprofitable projects that increase her power or stature. The conflict of interest between the borrower and lender stemming from moral hazard implies that many lenders will decide that they would rather not make loans, so that lending and investment will be at suboptimal levels. (Asymmetric information is clearly not the only source of the moral hazard problem. Moral hazard can also occur because high enforcement costs might make it too costly for the lender to prevent moral hazard even when the lender is fully informed about the borrower's activities.) In order to minimize the moral hazard problem, lenders must impose restrictions (restrictive covenants) 
and other contract terms on borrowers so that borrowers do not engage in behavior that makes it less likely that they can pay back the loan; then lenders must monitor the borrowers' activities and enforce the restrictive covenants if the borrower violates them.

Another concept that is very important in understanding the impediments to a wellfunctioning financial system is the so-called free-rider problem. The free-rider problem occurs because people who do not spend resources on collecting information can still take advantage of (free ride off) the information that other people have collected. The free-rider problem is particularly important in securities markets. If some investors acquire information that tells them which securities are undervalued and then buy these securities, other investors who have not paid for this information may be able to buy right along with the well-informed investors. If enough free-riding investors can do this, the increased demand for the undervalued securities will cause their low price to be bid up to reflect the securities' full net present value given this information. As a result of all these free riders, investors who have acquired information will no longer be able to earn the entire increase in the value of the security arising from this additional information. The weakened ability of private firms to profit from producing information will mean that less information is produced in securities markets, so that the adverse selection problem, in which overvalued securities are the those most often offered for sale, is more likely to be an impediment to a well-functioning securities market.

More importantly, the free-rider problem makes it less likely that securities markets will act to reduce incentives to commit moral hazard. As we have seen, monitoring and enforcement of restrictive covenants and other contract terms are necessary to reduce moral hazard incentives for borrowers to take on risk at the lenders expense. However, because monitoring and enforcement is costly, the free-rider problem discourages this kind of activity in securities markets. Once some investors know that other securities holders are monitoring and enforcing the restrictive covenants, they can free ride on the other securities holders' monitoring and enforcement. When these other securities holders realize that they can do the same thing, they also may stop their monitoring and enforcement activities, with the result that not enough resources are devoted to monitoring and enforcement. The outcome is that moral hazard can be a serious hindrance to the issuance of marketable securities.

One important feature of financial systems explained by the asymmetric information 
framework is the prominent role played by banking institutions and other financial intermediaries that make private loans. These institutions play such an important role because they are well suited to reduce adverse selection and moral hazard problems in financial markets. They are not as subject to the free-rider problem and profit from the information they produce because they make private loans that are not traded. Because the loans of these institutions are private, other investors cannot buy them. As a result, investors are less able to free ride off financial intermediaries and bid up the prices of the loans which would prevent the intermediary from profiting from its information production activities. Similarly, it is hard to free ride off these monitoring activities of financial intermediaries when they make private loans. Financial institutions making private loans thus receive the benefits of monitoring and so are better equipped to prevent moral hazard on the part of borrowers.

Banks have particular advantages over other financial intermediaries in solving asymmetric information problems. For example, banks' advantages in information collection activities are enhanced by their ability to engage in long-term customer relationships and issue loans using lines of credit arrangements (Petersen and Rajan, 1994, and Berger and Udell (1995). In addition their ability to scrutinize the checking account balances of their borrowers may provide banks with an additional advantage in monitoring the borrowers' behavior (Nakamura, 1993). Banks also have advantages in reducing moral hazard because, as demonstrated by Diamond (1984), they can engage in lower cost monitoring than individuals, and because, as pointed out by Stiglitz and Weiss (1983), they have advantages in preventing risk taking by borrowers since they can use the threat of cutting off lending in the future to improve a borrower's behavior. Banks also have advantages in contracting, that is, specifying interest rates, collateral requirements and other contractual terms that help sort borrowers into risk pools which reduce adverse selection and moral hazard incentives for borrowers to engage in risky activities. Banks' natural advantages in collecting information and reducing moral hazard explain why banks have such an important role in financial markets throughout the world. ${ }^{1}$ In addition, banks have the advantage of the synergy from providing liquidity provision

\footnotetext{
${ }^{1}$ As pointed out in Edwards and Mishkin (1995), the traditional financial intermediation role of banking has been in decline in both the United States and other industrialized countries because of improved information technology which makes it easier to issue securities. Nonetheless, banks continue to be
} 
at the same institution offering line of credit lending and deposits (see Kashyap, Rajan, and Stein 1999).

The asymmetric information framework explains why banks play an even more important role in the financial systems of emerging market and transition countries because of the greater difficulty of acquiring information on private firms in these countries. ${ }^{2}$ When the quality of information about firms is worse, asymmetric information problems will be more severe, and it will be harder for firms to issue securities. Thus the smaller role of securities markets in emerging market and transition countries leaves a greater role for financial intermediaries such as banks.

\section{3. Why is Prudential Supervision Needed?}

In the previous section, have seen how asymmetric information leads to adverse selection and moral hazard problems that have an important impact on the financial system and explain the importance of banks. The same asymmetric information analysis is especially useful in understanding why prudential supervision of the banking system is necessary and why governments chose the types of supervision they do.

\subsection{The Rationale for a Government Safety Net}

As we saw in the previous section, banks are particularly well suited to solving adverse selection and moral hazard problems because they make private loans that help avoid the freerider problem. However, this solution to the free-rider problem creates another asymmetric information problem because depositors lack information about the quality of these private loans. This asymmetric information problem leads to two reasons why the banking system might not function well.

important in the financial system.

${ }^{2}$ Rojas-Suarez and Weisbrod (1994) document that banks play a more important role in the financial systems in emerging market countries than they do in industrialized countries. 
First, in the absence of government intervention, a bank failure means that depositors would have to wait to get their deposit funds until the bank is liquidated and its assets turned into cash, and at that time, they would be paid only a fraction of the value of their deposits. Unable to learn if bank managers were taking on too much risk or were outright crooks, depositors would be reluctant to put money in the bank, thus making banking institutions less viable. Second is that depositors' lack of information about the quality of bank assets can lead to bank panics, which can have serious harmful consequences for the economy.

To see this, consider the following situation. After an adverse shock hits the economy, 5 percent of the banks have such large losses on loans that they become insolvent (have a negative net worth and so are bankrupt). Because of asymmetric information, depositors are unable to tell whether their bank is a good bank or one of the 5 percent that are insolvent. Depositors at bad and good banks recognize that they may not get back 100 cents on the dollar for their deposits and will want to withdraw them. Indeed, because banks operate on a sequential service constraint (a first-come, first-served basis), depositors have a very strong incentive to show up at the bank first because if they are last in line, the bank may run out of funds and they will get nothing. Uncertainty about the health of the banking system in general can lead to runs on banks both good and bad, and the failure of one bank can hasten the failure of others (a contagion effect). If nothing is done to restore the public's confidence, a bank panic can ensue. Because banks solve asymmetric information problems and thus facilitate productive investment in the economy, a bank panic in which many banks go out of business reduces the amount of financial intermediation undertaken by banks and so leads to a decline in investment and aggregate economic activity. Indeed, the most severe economic contractions in U.S. history have always been associated with banking panics (see Friedman and Schwartz, 1963, Bernanke, 1983, and Mishkin, 1991).

A government safety net for depositors can short-circuit runs on banks and bank panics, and by providing protection for the depositor, it can overcome reluctance to put funds in the banking system. One form of the safety net is explicit deposit insurance, a guarantee such as that provided by the Federal Deposit Insurance Corporation (FDIC) in the United States in which depositors are paid off in full on the first $\$ 100,000$ they have deposited in the bank no matter what happens to the bank. With fully insured deposits, depositors do not need to run to 
the bank to make withdrawals -- even if they are worried about the bank's health because their deposits will be worth 100 cents on the dollar no matter what.

Deposit insurance is not the only way in which governments provide a safety net for depositors. Governments have often stood ready to provide support to domestic banks when they face runs even in the absence of explicit deposit insurance. This support is sometimes provided by the central bank which operates as a lender of last resort, either by lending directly to troubled institutions or injecting liquidity into the financial system through open market operations (which may be less effective). In other cases, funds are provided directly by the government to troubled institutions, or these institutions are taken over by the government and the government then guarantees that depositors will receive their money in full.

\subsection{Moral Hazard and the Government Safety Net}

Although a government safety net can be very successful at protecting depositors and preventing bank panics, it is a mixed blessing. The most serious drawback of the government safety net stems from moral hazard, the incentives of one party to a transaction to engage in activities detrimental to the other party. Moral hazard is a prominent concern in government arrangements to provide a safety net. Because with a safety net depositors know that they will not suffer losses if a bank fails, they do not impose market discipline on banks by withdrawing deposits when they suspect that the bank is taking on too much risk. Consequently, banks with a government safety net have an incentive to take on greater risks than they otherwise would. The problem here is not just that a government safety net exists, but that it results in a payoff function for bank owners that encourages excessive risk taking. If the insurance provided by the safety net could be priced properly so that the payoff for the bank would no longer encourage excessive risk taking -- obviously, a tall order -- then the moral hazard problem would disappear.

\subsection{Adverse Selection and the Government Safety Net}

A further problem with a government safety net arises because of adverse selection, the fact that the people who are most likely to engage in activities that may cause bank failure are 
those who most want to take advantage of the insurance. Because depositors that are protected by a government safety net have little reason to impose discipline on the bank, risk-loving entrepreneurs might find the banking industry a particularly attractive one to enter -- they know that they will be able to engage in highly risky activities.

\subsection{Too-Big-To-Fail}

Because the failure of a very large bank makes it more likely that a major financial disruption will occur, governments are naturally reluctant to allow a big bank to fail and cause losses to its depositors and perhaps to other stakeholders. Indeed, when large banks have failed, as happened in the United States with the failure in May 1984 of Continental Illinois, one of the ten largest banks in the United States, governments often guarantee not only insured deposits, but also prevent losses for uninsured deposits or even bondholders. (Note that "too big to fail" term is somewhat misleading because when a bank is closed or merged into another bank, at least in the United States but not always elsewhere, the managers are usually fired and the stockholders in the bank lose their investment.)

One problem with the too-big-to-fail policy is that it increases the moral hazard incentives for big banks. If a government were willing to close a bank, preventing losses only for insured depositors, uninsured depositors or other creditors would suffer losses if the bank failed. Thus they would have an incentive to monitor the bank by examining the bank's activities closely and pulling their money out if the bank were taking on too much risk. To prevent such a loss of credit, the bank would be more likely to engage in less risky activities. However, once uninsured creditors know that a bank is too big to fail, they have no incentive to monitor the bank and pull out their funds when it takes on too much risk: No matter what the bank does, uninsured creditors will not suffer any losses. The result of the too-big-to-fail policy is that big banks might take on even greater risks, thereby making bank failures more likely. Boyd and Gertler (1993) find evidence consistent with this view because they found that large banks in the United States took on riskier loans than smaller banks and that this led to higher loan losses for the large banks.

\subsection{Rationale for Prudential Supervision}


Because all governments provide some form of a safety net for the banking system, whether it is explicit or implicit, they need to take steps to limit the moral hazard and adverse selection that the safety net creates. Otherwise, banks will have such a strong incentive to take on excessive risks that the safety net may do more harm than good and promote banking crises rather than prevent them. Prudential supervision, in which the government establishes regulations to reduce risk taking and then supervisors monitor banks to see that they are complying with these regulations and not taking on excessive risk, is thus needed to ensure the safety and soundness of the banking system. Preventing excessive risk-taking with prudential supervision is even more critical in emerging market countries, as recent events have indicated. Inadequate prudential supervision has led to severe problems in these countries banking sectors which have been an important factor triggering the currency and financial crises in these countries in recent years, which have created so much economic hardship (see Mishkin, 1996, 1999 and Corsetti, Pesenti, and Roubini, 1998)

\section{4. Forms of Prudential Supervision}

Prudential supervision takes on eight basic forms: 1) restrictions on asset holdings and activities, 2) separation of the banking and other financial industries like securities, insurance, or real estate, 3) restrictions on competition, 4) capital requirements, 5) risk-based deposit insurance premiums, 6) disclosure requirements, 7) bank chartering, 8) bank examination, and 9) a supervisory versus a regulatory approach.

\subsection{Restrictions on Asset Holdings and Activities}

Even in the absence of a government safety net, banks still have the incentive to take on too much risk. Risky assets may provide the bank with higher earnings when they pay off; but if they do not pay off and the bank fails, depositors are left holding the bag. If depositors were able to monitor the bank easily by acquiring information on its risk-taking activities, they would immediately withdraw their deposits if the bank was taking on too much risk. To prevent 
such a loss of deposits, the bank would be more likely to reduce its risk-taking activities. Unfortunately, acquiring information on a bank's activities to learn how much risk the bank is taking can be a difficult task. Hence depositors may be incapable of imposing discipline that might prevent banks from engaging in risky activities. A rationale for government regulation to reduce risk taking on the part of banks therefore exists even without the presence of a government safety net such as deposit insurance. ${ }^{3}$ The need for restrictions on risky activities is even greater when there is a government safety net which increases the incentives for risky behavior.

Governments therefore impose banking regulations that restrict banks from holding risky assets -- common stock, for example in the United States --and these restrictions are a direct means of making banks avoid too much risk. ${ }^{4}$ Bank regulations also promote diversification, which reduces risk by limiting the amount of loans in particular categories or to individual borrowers. Regulations also restrict banks from engaging in commercial activities which are considered to be outside the core banking business, which might subject the bank to too much risk.

\subsection{Separation of Banking and other Financial Service Industries}

One particular type of activity that may involve more risk than traditional banking activities is underwriting securities. Concerns that moral hazard incentives created by the government safety net might encourage excessive risk in this business has led some governments to prevent the combination of banking and securities activities. For example, the Glass-Steagall Act of 1933 forced a separation of the banking and securities industries in the United States until its repeal with the passage in 1999 of the Gramm-Leach-Bliley, Financial Services Modernization Act.

\footnotetext{
${ }^{3}$ However, even if most depositors are unable to monitor banks activities sufficiently well to discipline them, banks structured with more equity or subordinated claims would not rely on depositors for discipline and junior claimants might then be able to provide more of the required discipline.

${ }^{4}$ Preventing banks from holding individually risky assets does not necessarily reduce the variance of their portfolios and this is why regulators also focus on the overall riskiness of the bank's balance sheet and activities.
} 
Another concern with banks engaging in other financial activities such as securities underwriting, insurance or real estate is that this may lead to extension of the government safety net to these industries also, even if these industries are not inherently riskier than traditional banking. As we have seen, expansion of the safety could increase the incentives for risk taking in nonbanking industries, which could make the financial system more fragile. In addition, extending the safety net to units of banking institutions that engage in securities, insurance and real estate activities might give banking institutions an unfair competitive advantage in these industries relative to companies not affiliated with banks. Thus governments often restrict banks from entering these other businesses in order to prevent extension of the safety net.

\subsection{Restrictions on Competition}

Increased competition can also increase moral hazard incentives for banks to take on more risk. Declining profitability and hence a lower franchise value as a result of increased competition could tip the incentives of bankers toward assuming greater risk in an effort to maintain former profit levels. ${ }^{5}$ Thus governments in many countries have instituted regulations to protect banks from competition. These regulations have taken four forms. First are regulations separating banking and nonbanking business, like those in the Glass-Steagall legislation discussed immediately above, which prevents nonbank institutions from competing with banks by engaging in banking business. Second are restrictions on entry of foreign banks (or in the United States, restrictions on entry of out-of-state banks which occurred before implementation of the Riegle-Neal, Interstate Banking and Branching Efficiency Act of 1994). Third are restrictions on branching. Fourth is ceilings on rates charged on loans or ceilings on rates charged on deposits, as with the Regulation Q restrictions on deposit rates in the United States which were abolished in the mid 1980s.

Although restricting competition may prop up the health of banks, restrictions on competition have obvious serious disadvantages: They can lead to higher charges to consumers and can decrease the efficiency of banking institutions, which do not have to compete as hard (Berger and Hannan, 1998). Thus although the existence of asymmetric information provides

\footnotetext{
${ }^{5}$ See Marcus (1984) and Keeley (1990).
} 
a rationale for anticompetitive regulations, it does not mean that they will be beneficial. Indeed, in recent years, the impulse of governments in industrialized countries to restrict competition has been waning.

\subsection{Capital Requirements}

Requirements that banks have sufficient capital are another way to change the bank's incentives to take on less risk. When a bank is forced to hold a large amount of equity capital, the bank has more to lose if it fails and is thus more likely to pursue less risky activities.

Bank capital requirements typically take three forms. The first type is based on the socalled leverage ratio, the amount of capital divided by the bank's total assets. For example, in the United States to be classified as well capitalized, a bank's leverage ratio must exceed 5 percent; a lower leverage ratio, especially one below 3 percent, triggers prompt corrective action with increased restrictions on the bank.

In the wake of banking problems in the 1980s, regulators in the United States and the rest of the world have become increasingly worried about banks' holdings of risky assets and about the increase in banks' off-balance-sheet activities, particularly activities that involve trading financial instruments and generating income from fees, which do not appear on bank balance sheets but nevertheless expose banks to risk. This led to establishment of a second type of capital requirements in 1988 which attempt to make adjustments for risk, referred to as the Basel Accord on bank capital requirements because they were agreed to by banking officials from industrialized nations, who met under the auspices of the Bank for International Settlements in Basel, Switzerland. Under this risk-based capital requirement, minimum capital standards are linked to off-balance-sheet activities such as loan commitments, letters of credit, interest-rate swaps and trading positions in futures and options.

The Basel Accord required that banks hold capital of at least $8 \%$ of their risk-weighted assets. Assets and off-balance sheet activities were allocated into four categories, each with a different weight to reflect the degree of credit risk. The first category carried a zero weight and included items that have little default risk, such as reserves and government securities in the OECD (industrialized) countries. The second category had a $20 \%$ weight and included claims on banks in OECD countries. The third category had a weight of $50 \%$ and included 
municipal bonds and residential mortgages. The fourth category had the maximum weight of $100 \%$ and included credits to consumers and corporations. Off-balance-sheet activities are treated in a similar manner by assigning a credit-equivalent percentage that converts them to on-balance-sheet items to which the appropriate risk weight applies.

A third type of capital requirement was introduced in 1996 to cover risk in trading activities at the largest banks. For example, since January 1998, the Federal Reserve requires these banks to use their own internal models to calculate how much they could lose over a tenday period and then set aside additional capital equal to three times that amount. Banks can meet this new capital requirement with more standard forms of capital or by issuing a new form of capital, called Tier 3, which consists of short-term securities that holders cannot cash in at maturity if the bank is undercapitalized.

\subsection{Risk-Based Deposit Insurance Premiums}

As was mentioned in Section 3.2, the government safety net creates a moral hazard problem because it leads to a payoff function for bank owners that encourages excessive risktaking. The moral hazard problem could therefore be eliminated if premiums for the insurance provided by the government were priced appropriately to reflect the amount of risk taken by a bank. The Federal Deposit Insurance Corporation Act (FDICIA) of 1991 pursued this approach to reducing the moral hazard problem by mandating the implementation of risk-based deposit insurance premiums. As a result, deposit insurance premiums in the United States are based on bank's classifications into one of three capital adequacy groups and one of three supervisory groups. The higher is capital adequacy and the better is the bank's supervisory rating, the lower is its insurance premium.

Although risk-based deposit insurance premiums are desirable in theory, in practice they have not worked very well. The basic problem is that it is hard to accurately determine the amount of risk a bank is actually taking. For example, at the beginning of 1999, 95 percent of the Bank Insurance Fund institutions in the United States (with 98 percent of commercial bank deposits) and 92 percent Savings Association Insurance Fund institutions (with 96 percent of savings and loan deposits) ended up being put in the least risky insurance category, paying a zero insurance premium. Clearly, the risk-based deposit insurance scheme in the United States 
does not discriminate adequately among banks and has not provided the appropriate incentives to reduce risk taking.

\subsection{Disclosure Requirements}

The free-rider problem described above indicates that individual depositors and other bank creditors will not have enough incentive to produce private information about the quality of a bank's assets. To ensure that there is better information for depositors and the marketplace, regulators can require that banks adhere to certain standard accounting principles and disclose a wide range of information that helps the market assess the quality of a bank's portfolio and the amount of the bank's exposure to risk. More public information about the risks incurred by banks and the quality of their portfolio can enhance market discipline by enabling stockholders, creditors, and depositors to evaluate and monitor banks and so act as a deterrent to excessive risk taking. Disclosure requirements can also be the primary focus of a bank regulatory system, as with the approach implemented in New Zealand in 1996 in which every bank must supply a comprehensive quarterly financial statement to the public and prominently post its rating from private credit agencies at all bank branches. An unusual feature of the New Zealand system is that it requires bank directors to validate financial statements, and they are subject to unlimited liability if the bank goes into bankruptcy and these financial statements are found to be misleading.

\subsection{Bank Chartering}

Overseeing who operates banks is an important method for reducing the adverse selection problem created by the government safety net. Because banks can be used by dishonest people or overly ambitious entrepreneurs to engage in highly speculative activities, such undesirable people (from the safety and soundness perspective) would be eager to run a bank. Chartering banks is one method for preventing this adverse selection problem -- through chartering, proposals for new banks are screened to prevent undesirable people from controlling 
them. The typical chartering process requires the people planning to organize the bank to submit an application that shows how they plan to operate the bank. In evaluating the application, the chartering authority looks at whether the bank is likely to be sound by examining the quality of the banks' intended management, the likely earnings of the bank, and the amount of the bank's initial capital. ${ }^{6}$

\subsection{Bank Examination}

In order to limit moral hazard incentives for excessive risk taking, it is not enough to have regulations which encourage less risk taking, but banks must be monitored to see if they are complying with these regulations -- and if not, enforcement actions must be taken. Banks are required to file periodic (usually quarterly) reports (called "call reports" in the United States) that contain such information as the bank's assets and liabilities, income and dividends, ownership, foreign exchange operations, and other details. Bank examiners also evaluate the quality of a bank's loans and classify them into problem categories if they are unlikely to be repaid in order to assess the bank's balance-sheet position and the amount of its capital. This information along with regular on-site bank examinations allow regulators to monitor whether the bank is complying with capital requirements (including sufficient provisioning for loan losses), restrictions on asset holdings, disclosure requirements, etc., and are crucial to limiting the moral hazard created by the government safety net. ${ }^{7}$

In the United States, with variants in other countries, examiners give banks a so-called CAMELS rating (the acronym is based on the six areas assessed: capital adequacy, asset quality, management, earnings, liquidity, and sensitivity to market risk). With this information about a bank's activities, regulators can enforce regulations by taking such formal actions as cease and desist orders to alter the bank's behavior or even close a bank if its supervisory rating

\footnotetext{
${ }^{6}$ Chartering can also be used to restrict entry and competition. For example, in the past to get a charter from the Office of the Comptroller of the Currency in the United States, a bank had to demonstrate a need for a new bank. However, the use of chartering to restrict competition is no longer a feature of the chartering process in the United States.

${ }^{7}$ For a description of the bank examination process in the United States, see the paper by Berger, Kyle and Scalise in this volume.
} 
is sufficiently low. Actions taken to reduce moral hazard by restricting banks from taking on too much risk also help reduce the adverse selection problem because with less opportunity for risk taking, risk-loving entrepreneurs will be less likely to be attracted to the banking industry.

\subsection{The Supervisory Versus the Regulatory Approach}

Traditionally, prudential supervision has focused primarily on assessment of the quality of the bank's balance sheet and loans at a point in time and then determines whether the bank complies with capital requirements and restrictions on asset holdings. Because this kind of prudential supervision is based on regulatory rules, it is often referred to as the "regulatory approach." Although the traditional "regulatory approach" is important for reducing excessive risk taking by banks, it is no longer felt to be adequate in today's world in which financial innovation has produced new markets and instruments that make it easy for banks and their employees to make huge bets easily and quickly. In this new financial environment, a bank that is quite healthy at a particular point in time can be driven into insolvency extremely rapidly from trading losses, as forcefully demonstrated by the failure of Barings in 1995. Thus an examination that focuses only on the quality of the bank assets or whether a bank is following the rules at a point in time, may not be effective in indicating whether a bank will in fact be taking on excessive risk in the near future.

This change in the financial environment for banking institutions has resulted in a major shift in thinking about the bank supervision process throughout the world to what is called the "supervisory approach." In the "supervisory approach" bank examiners focus less on compliance with specific regulatory rules and the risks of the financial instruments currently in the bank's portfolio and more on the soundness of the bank's management practices with regard to controlling risk. This shift in thinking was reflected in a new focus on risk management in the Federal Reserve System's 1993 guidelines to examiners on trading and derivatives activities. The focus was expanded and formalized in the Trading Activities Manual issued early in 1994, which provided bank examiners with tools to evaluate risk management systems. In late 1995, the Federal Reserve and the Comptroller of the Currency announced that they would be assessing risk management processes at the banks they supervise. Now bank examiners give a separate sensitivity to risk rating from 1 to 5 that feeds into the overall 
management rating as part of the CAMELS system. Four elements of sound risk management are assessed to come up with the sensitivity to risk rating: (1) The quality of oversight provided by the board of directors and senior management, (2) the adequacy of policies and limits for all activities that present significant risks, (3) the quality of the risk measurement and monitoring systems, and (4) the adequacy of internal controls to prevent fraud or unauthorized activities on the part of employees.

This shift toward focusing on management processes is also reflected in recent guidelines adopted by the U.S. bank regulatory authorities to deal with interest-rate risk. At one point, U.S. regulators were contemplating requiring banks to use a standard model to calculate the amount of capital a bank would need to have to allow for the interest-rate risk it bears. Because coming up with a one-size-fits-all model that would work for all banks has proved difficult, the regulatory agencies have instead decided to adopt guidelines for the management of interest-rate risk, and bank examiners will continue to consider interest-rate risk in deciding on the bank's capital requirements. These guidelines require the bank's board of directors to establish interest-rate risk limits, appoint officials of the bank to manage this risk, and monitor the bank's risk exposure. The guidelines also require that senior management of a bank develop formal risk management policies and procedures, to ensure that the board of director's risk limits are not violated and to implement internal controls to monitor interest-rate risk and compliance with the board's directives.

The Basel Committee on Bank Supervision has also moved more toward the "supervisory approach" in deciding on capital requirements. One part of its June 1999 proposal would allow banks to use their own credit risk models for setting capital requirements, while the internal management procedures banks use to decide on how much capital to hold would be subject to supervisory review, after which banks might be required to hold capital beyond the regulatory minimum in some circumstances. The movement away from rules-based prudential supervision, the "regulatory approach," toward a more forward-looking "supervisory approach" will probably increase over time. However, bank regulations will still play a prominent role in prudential supervision, not only because they are a first defense against excessive risk taking, but also because their existence provides supervisors with a stick they can wield to get banks to implement proper risk management procedures. 


\section{5. \\ What Are the Issues?}

The framework used here to understand why prudential supervision is needed and the forms that it takes, can also be used to examine key issues affecting whether prudential supervision will work well in preserving the safety and soundness of the banking system, the topic of this conference. There are eight basic issues that we look at here, and the papers in this conference volume have something to say about all of them.

\subsection{How Restrictive Should a Regulatory Environment Be?}

We have seen that prudential supervision often takes the form of restricting bank activities, either by not allowing them to hold certain assets or by restricting them from engaging in certain businesses. Although restricting banks from certain activities may limit the opportunities for banks to take on risk, this does not mean that doing so will be always be beneficial or will promote the safety and soundness of the financial system.

For example, those who are opposed to restrictions separating the banking and other financial industries believe that allowing banks to enter these industries would increase competition. Bank entry into securities underwriting can lower the spreads between the price guaranteed to the issuer of the security and the price paid for the security by the public, possibly increasing the efficiency of securities markets (see Beatty, Thompson and Vetsuypens, 1998, and Gande, Puri and Saunders, 1999). Bank entry into insurance could create more efficient networks to deliver insurance to consumers, thereby lowering costs. Furthermore, combination of banking and nonbanking business under one roof could lead to more diversified financial institutions which may thus be less likely to fail. Thus, allowing banks to enter other financial industries could actually increase the safety of the financial system, rather than making it more fragile.

Proponents of separation of the banking and other industries such as investment banking and real estate which can be quite risky believe that allowing commercial banks to engage in 
this business might produce more bank failures and a less stable financial system. They also are concerned about potential conflicts of interest if banks engage in underwriting securities. Congressional hearings in the United States prior to the enactment of the Glass-Steagall Act in 1933 turned up abuses in which banks that were underwriting new issues of securities sold them to trust funds they managed when they could not sell them to anyone else, and these trust funds often suffered substantial losses when the securities where sold later. Cases also surfaced in which the bank would buy securities that it was underwriting when the securities could not be sold elsewhere. Proponents of separation of banking from other financial industries also worry that the extension of the safety net to these other industries will remove market discipline and encourage risk taking in these industries which could reduce their safety and soundness.

Proponents of abolishing the separation of banking and the securities industries point out that the extent of underwriting abuses that occurred before the passage of Glass-Steagall were probably exaggerated (see Benston, 1990), and regulatory authorities now have much greater power to find and punish people who would abuse commercial banking's securities activities. Empirical research suggests that conflicts of interest which would lead to underwriting abuses are not a serious problem (see Ang and Richardson, 1994, Kroszner and Rajan, 1994 and 1997, Puri, 1994 and 1996, Gande, Puri, Saunders and Walter, 1997, and Gande, Puri and Saunders, 1998). Furthermore, the erection of "fire walls" to separate various bank operations can help prevent conflicts of interest. Fire walls could also be useful in limiting the expansion of the safety net to other businesses, including securities and insurance underwriting.

A key issue for the design of prudential supervision is thus, what regulatory environment works best and how restrictive it should be? The paper by James Barth, Gerard Caprio, Jr., and Ross Levine in this volume examines this issue by exploiting a unique data set they have created at the World Bank which documents the nature of the regulatory environment and restrictions in a panel of over sixty countries. Through statistical analysis, they evaluate the links between different regulatory/ownership practices and financial sector performance and banking-system stability. They ask three basic questions and get the following answers.

First, do countries with regulations that impose tighter restrictions on the ability of commercial banks to engage in securities, insurance and real estate activities have less efficient 
but more stable financial systems? Barth, Caprio and Levine uncovered no reliable statistical relationships between regulatory restrictions on banks engaging in securities, insurance and real estate activities and the level of financial development or industrial competition. However, they do find that restrictions on banks engaging in securities activities tend to be associated with higher interest rate margins, suggesting that these restrictions hamper efficiency. Furthermore, countries with greater regulatory restrictions on securities activities of commercial banks have a significantly and substantially higher probability of suffering a financial crisis. The evidence in this paper thus suggests that regulatory restrictions separating banking and other financial industries, especially the securities industry, are harmful. Allowing banks to enter the securities industry not only promotes efficiency, but can actually promote a more stable financial system. Evidence of the type in this paper can never be conclusive, as the discussant, Mark Gertler, points out, but the paper shifts the burden of proof onto those who advocate separation of banking and the securities industries to demonstrate harmful effects of allowing banks into this industry.

The second question, Barth, Caprio and Levine ask is whether countries that restrict the mixing of banking and commerce have less efficient but more stable financial systems? They do not find that restrictions on mixing banking and commerce hurt efficiency or financial development, but do find that these restrictions are associated with greater financial instability. Thus, one of the major reasons for restricting the mixing of banking and commerce, to reduce financial fragility, is not supported by the evidence in this paper. This evidence, along with the evidence on the first question, weakens the case for more restrictive regulatory environments for the banking system.

The third question asks whether having a large role of state-owned banks in the financial system leads to more poorly functioning financial systems? They find that the answer is yes because greater state ownership of banks in a country tends to be associated with more poorly developed banks, nonbanks and securities markets. This result accords well with economists' intuition who believe that the private sector has much better incentives to create financial institutions that will make the financial system operate efficiently. This evidence accords well with many economists' recommendations that the government should not be in the financial business, but should instead leave it to the private sector. 


\subsection{Limiting Too-Big-To-Fail}

As we have seen, the too-big-to-fail problem provides a particular challenge for prudential supervision. Governments are reluctant to let the failure of particularly large banking institutions causes losses for depositors and often other stakeholders because the failure is then more likely to have a systemic effect on the financial system, thereby precipitating a financial crisis. On the other hand, this reluctance increases moral hazard incentives for large banking institutions to take on excessive risk, which makes the financial system more fragile. Thus a key issue for prudential supervision is how to limit the moral hazard incentives for large banking institutions.

The speech given at the conference by Lawrence Meyer, a governor of the Federal Reserve System, addresses the issue of how the Federal Reserve System is approaching the supervision of what he calls Large Complex Banking Organizations. This issue has grown in importance recently, with the growth of financial consolidation and the passage of the GrammLeach-Bliley Act of 1999 which encourage the development of larger and complex financial organizations. Meyer's speech indicates that the Federal Reserve has groups who are engaged in intensive study of how best to supervise these large organizations and that the Fed's thinking is taking two directions. First, there is a growing emphasis on a supervisory approach in which examiners focus on the adequacy of banks' risk management and internal models to determine the amount of capital needed to cope with market and credit risk. Second, there is increased emphasis on the use of market discipline to create the right incentives for these large, complex banking organizations.

In order to enhance market discipline, Meyer cites two steps that can be taken. First, are requirements to increase public disclosure of information about residual risk in securitizations, the distribution of credits by internal risk classifications and concentrations of credits by industry, geography and borrower. This disclosure should make it easier for the market to judge whether these large banks are managing risk properly and pull out funds if they have concerns about the way the bank is managing risk. Second, an increase in issuance by large banking organizations of subordinated debt (junior debt that is paid off only after more senior claims have been paid). This subordinated debt will subject them to increased market discipline because subordinated debt holders have strong incentives to monitor these 
organizations.

\subsection{Market Discipline}

The importance of market discipline and how it might work to promote safety and soundness of the financial system is not only a theme in Meyer's speech, but is also in the papers by Robert Bliss and Mark Flannery and Charles Calomiris and Andrew Powell.

The term "market discipline" has often been used quite loosely in the literature and Bliss and Flannery make the important point that the concept of market discipline needs to be refined if we are to understand its effectiveness. Bliss and Flannery distinguish between two aspects of market discipline: 1) "monitoring" in which investors are able to accurately understand changes in a firm's condition and incorporate these assessments promptly into the firm's security prices; and 2) "influence" in which a security price decline causes firm managers to respond by counteracting adverse shocks. There is substantial evidence that markets are able to monitor and reflect a firm's financial condition in securities prices (see the survey in Flannery, 1998). On the other hand there is very little evidence in the literature on whether there is market influence in non-extreme situations. ${ }^{8}$ Without market influence in which market prices cause managers to alter their behavior in normal times, market monitoring will not necessarily limit managers of financial institutions from taking on excessive risk. Thus without market influence, market discipline will not work.

Bliss and Flannery study market influence by examining what happens to the condition of bank holding companies after stock and bond price changes in order to see if there is evidence that these price changes affect managerial actions. They do not find convincing evidence of market influence, but as is indicated in the paper and by the discussant, Raghuram Rajan, because securities prices may primarily reflect predictions of future financial conditions, managerial actions that counteract adverse shocks may be extremely difficult to find in the data even if this is exactly what the managers are doing. Rather than indicating that market

\footnotetext{
${ }^{8}$ An example of extreme situations would be one of near-insolvency or very poor firm performance that might trigger a takeover.
} 
influence is weak, the Bliss and Flannery paper instead demonstrates how difficult it is to use market prices to obtain evidence on the existence of market influence. However, their paper suggests that without strong evidence for the ability of markets to influence managerial actions, prudential supervisors should retain responsibility for influencing managerial actions to restrict risk taking.

In recent years, Argentina has undertaken a sweeping reform of its system of prudential supervision, particularly in the aftermath of the Tequila crisis in 1994, using greater reliance on market discipline to promote a safe and sound banking system. The paper by Calomiris and Powell outlines what changes Argentina has made in its supervisory system and assesses how well these changes have worked to create credible market discipline of the banking system. The Argentinean experience is worth studying not only for the lessons it provides to emerging market countries, but also for the lessons it may provide for industrialized countries like the United States, which, as Meyer's speech indicates, are considering increasing the use of market discipline in their supervisory systems.

In the aftermath of the Tequila crisis, Argentina adopted the BASIC system of banking oversight, administered by the central bank, with BASIC an acronym that stands for Bonds, Auditing, Supervision, Information and Credit Rating. The main concept behind this system is that market discipline and regulatory discipline are each imperfect by themselves, but there is a strong complementarity between the two. The Argentineans recognized, as Meyer does in his speech, that information is a prerequisite to market or regulatory discipline. Thus a key feature of the BASIC system is increased disclosure of information (the "I" in BASIC), including development of a credit bureau in which information about all loans in the financial system above $\$ 50$ in value are made publicly available. Information disclosure is useful only if the information is accurate. Thus another key feature of the BASIC system is the supervisory authority's setting standards and supervision of the auditing process (the "A" in BASIC). To increase information, the BASIC system also has a Credit Rating requirement (the "C" in BASIC) in which banks are required to obtain credit ratings and disclose them to the public. To increase market discipline, the BASIC system requires banks to issue subordinated debt for $2 \%$ of their deposits each year (the "B" for Bonds in BASIC). If banks are forced to attract investors by going to the market and issue subordinated debt, this process reveals information 
about the bank to both debtholders and supervisors. In addition, subordinated debt holders have incentives to monitor banks and pull out their funds if the bank is taking on too much risk. In addition to the above elements which focus on information and market discipline, the BASIC system has an important role for supervision (the "S" in BASIC). The supervisory authority adopted a version of the CAMELS system used in the United States and uses CAMELS ratings to set capital requirements.

Calomiris and Powell find that although the BASIC system has worked reasonably well, elements of it are not without their problems. The subordinated debt requirement, which was to be in place by January 1998, has not worked as well as some of its advocates had hoped. The Asian crisis in mid 1997 and the Russian crisis in the fall of 1998 made debt issues very difficult for the banks. Thus the central bank put back the compliance date for subordinated debt requirements several times and weakened the requirement by increasing the range of liabilities banks could issue to satisfy the requirement. In addition, the central bank has been unwilling to disclose which banks have been unable to comply with the sub debt requirement. However, the sub debt requirement has been beneficial in that it is the weak banks which have had trouble issuing sub debt and there have been penalties for non-compliance, giving banks incentives to decrease the riskiness of their activities. The credit ratings requirement has also run into some difficulties because obtaining the ratings appeared to be expensive and the ratings were not of uniform quality. The central bank has tried to fix these problems by asking banks to have only one rating to reduce the cost, and has restricted the number of authorized agencies to only internationally active ones.

On the whole, Calomiris and Powell give a fairly favorable assessment to the BASIC system. Not only has the Argentinean banking system grown rapidly and withstood shocks from the Asian and Russian crises, but the BASIC system seems to have injected credible market discipline into the banking system. They find there are market reactions to bank default risk as measured by deposit interest rates and deposit growth, and find that deposit interest rates mean revert quickly, especially after BASIC was implemented. These findings, although subject to some criticisms as indicated by the discussant, Douglas Diamond, suggest that the market can measure bank risk and punishes banks which are riskier and that banks try to reduce risk after they are exposed to risk-increasing shocks. Calomiris and Powell thus provide a more 
encouraging view of the effectiveness of market discipline than Bliss and Flannery. However, their assessment of Argentina's BASIC system does indicate that there is still an important role for bank examination and supervision in promoting safety and soundness of the banking system and that market discipline is not enough.

\subsection{Limiting the Principal-Agent Problem in Supervision}

An important impediment to successful prudential supervision of the financial system is the principal-agent problem in which the agent (a regulator or supervisor) does not have the same incentives as the principal (the taxpayer they work for) and so act in their own interest rather than in the interest of the principal. To act in the taxpayer's interest, regulators and supervisors have several tasks, as we have seen. For example, they need to set restrictions on holding assets that are too risky, impose sufficiently high capital requirements, and close down insolvent institutions. However, because of the principal-agent problem, regulators have incentives to do the opposite and engage in regulatory forbearance. One important incentive for regulators that explains this phenomenon is their desire to escape blame for poor performance by their agency. By loosening capital requirements and pursuing regulatory forbearance, regulators can hide the problem of an insolvent bank and hope that the situation will improve, a behavior that Kane (1989) characterizes as "bureaucratic gambling". Another important incentive for regulators is that they may want to protect their careers by acceding to pressures from the people who strongly influence their careers, the politicians.

Limiting the principal-agent problem by making bank supervisors accountable if they engage in regulatory forbearance is important to improve incentives for them to do their job properly. For example, as pointed out in Mishkin (1997a), an important but very often overlooked part of FDICIA which has helped make this legislation effective is that there is a mandatory report that the supervisory agencies must produce if the bank failure imposes costs on the Federal Deposit Insurance Corporation (FDIC). The resulting report is made available to any member of Congress and to the general public upon request, and the General Accounting Office must do an annual review of these reports. Opening up the actions of bank supervisors to public scrutiny makes regulatory forbearance less attractive to them, thereby reducing the principal-agent problem. In addition, subjecting the actions of bank supervisors to public 
scrutiny reduces the incentives of politicians to lean on supervisors to relax their supervision of banks.

Although limiting the principal-agent problem in bank supervision was not the main focus of any paper in the conference, the Calomiris and Powell paper and the paper by Allen Berger, Margaret Kyle and Joseph Scalise do have some useful things to say about this issue.

Calomiris and Powell point out that an additional benefit of the subordinated debt requirement in Argentina is that it helps monitor bank supervisors: failure to comply sends a signal that can discourage regulatory forbearance. When a weak bank fails to comply with the subordinated debt requirement, it makes it very hard for the supervisors to claim that they were unaware of the bank's problems because the market has provided a clear signal of its lack of confidence in the bank. The presence of the subordinated debt requirement thus avoids "plausible deniability" by supervisors, which makes it more likely that they will close down a weak bank or take actions to encourage it to return to health.

One question examined in the Berger, Kyle and Scalise paper is whether supervisors got tougher during the 1989-92 period and then got easier in the following period form 1993-98. Although Berger, Kyle and Scalise found some limited evidence that supervisors were tougher in the 1989-92 period, they found even stronger evidence that bank supervisors eased up on banks during the 1993-98 period. This finding of easing in the 1993-98 period is particularly interesting because it was during this period that there was tremendous political pressure on supervisors to relax standards: politicians claimed that supervisory action actions during the 1989-92 period were to blame for creating the "credit crunch" which put a significant damper on the economy. In 1993, supervisors formally recognized a problem of credit availability and began a joint program directed at dealing with this problem, taking actions designed to alleviate the apparent reluctance of institutions to lend. The results of this paper thus suggest that despite the supposed independence of bank supervisors in the United States and provisions in FDICIA to reduce the principal-agent incentives for supervisors to relax standards, bank supervisors in the United States might still be responsive to political pressure -- although an alternative view is that they were just trying to respond appropriately to a problem in the economy. The paper's results thus suggest that the principal-agent problem may not have been completely solved in the United States despite efforts to do so. 


\subsection{Refining Capital Requirements}

The Basel Accord on capital requirements was developed to make capital requirements responsive to the amount of credit risk borne by the bank. Over time, limitations of the Basel Accord have become apparent because the broad brush, regulatory measure of bank risk as stipulated by the credit risk weights can differ substantially from the actual risk the bank faces. For example, a loan to a AAA-rated corporation receives the same $100 \%$ risk weight (i.e., $8 \%$ capital requirement) as a highly risky loan to a CCC-rated corporation. As a result, banks may engage in what is called "regulatory (capital) arbitrage" in which they end up substituting riskier assets in their portfolio for safer assets which have the same risk weight. Thus riskbased capital requirements like the Basel requirements may end up encouraging risk-taking by banks rather than limiting it. Meyer in his speech notes this problem and worries that the incentive to arbitrage economic and regulatory capital will increase, giving regulatory capital less and less meaning.

A key issue for effective prudential supervision is whether capital requirements can be refined so that requirements ensure that banks have adequate capital to deal with the amount of credit risk in the bank's activities. The Basel Supervisors Committee (1999) has outlined two potential approaches to credit risk capital requirements for consideration: 1) a revised "standardized" approach similar in style to the current requirements, which leaves in place many of the distortions that lead to capital arbitrage; 2) an "internal ratings" approach in which required capital would be computed using formulas based on internal credit risk ratings done by the bank. Over the longer term, a move to an "internal models" approach, similar to that used for market risk, may be possible. Under this approach banks' internal models would be used to calculate the risk requirement. The "internal ratings" and "internal models" approaches would attempt to get regulatory capital requirements to more closely match economic capital. The internal models approach takes a supervisory approach to capital regulation because the bank would make decisions about the models used and then the supervisory authorities would monitor these models to see if they are reasonably accurate and follow best practice. The internal ratings approach has more elements of a regulatory approach because the parameters and architecture of the system would be set by regulators, although supervisors would still monitor the bank's procedures for determining the internal ratings. 
In order for the two new approaches to risk-based capital requirements to get regulatory capital close to economic capital, so that regulatory arbitrage would be minimized, technical knowledge about what portfolio characteristics and factors are important in exposing the bank to credit risk is crucial. Mark Carey's paper conducts Monte Carlo simulation exercises to see which asset or portfolio characteristics and types of behavior substantially expose the bank to risk and whether a linear structure, in which different credit risks are added up independently, accurately reflects total credit risk for the bank. The basic findings of this work, and also the results from similar work done at the Bank of England, reported on by the discussant, Patricia Jackson, are that credit risk is substantially influenced by the following factors: borrower default ratings, estimates of likely loss given a default, measures of portfolio size and granularity (the extent loans to a few borrowers make up a large fraction of the portfolio). In addition, the linear structure which is inherent in the internal ratings approach seems to produce reasonable estimates of overall credit risk for the bank. This research is useful to both banking institutions which need to develop their own internal models to assess credit risk, as well as to supervisors who may have to evaluate these internal models or regulators who might be designing an internal ratings approach to credit-risk-based capital requirements.

\subsection{How are Regulations Produced?}

Economic analysis is useful to design regulation to achieve certain objectives, and many of the papers in this conference are attempts to provide exactly this analysis. However, even when economists reach a consensus about what form regulation should take, we often see that the real world produces something quite different. For example, almost all American banking economists have agreed for over two decades that abolition of restrictions on branching across state lines would not only improve the efficiency of the banking sector, but would also increase diversification and make the banking system more stable. Yet despite this consensus, it was only in 1994, with the passage of the Riegle-Neal, Interstate and Branching Efficiency Act, that these restrictions were finally abolished. Why does it take so long for welfare-enhancing reforms to get implemented and what finally leads to passage of these reforms?

The paper by Randall Kroszner and Phillip Strahan looks at this question by using a political economy approach to analyze why regulations evolve as they do and what forces lead 
to passage of legislation that changes regulations. They analyze voting patterns in Congress on three amendments to the Federal Deposit Insurance Corporation Improvement Act of 1991 and find that private interests are a key determinant of votes on banking regulations, although partisanship and ideology also have an important role. Although the ability of their privateinterest model to explain individual votes is impressive, the discussant, Jeremy Stein, points out that their model of interest group competition and battle among private interests may not be quite as good at explaining regulatory outcomes as the regression results indicate. The problem is that median votes and not individual votes determine whether legislation is passed, so that accurate prediction of individual votes may not always translate into accurate prediction of whether legislation is actually passed.

Nonetheless, Kroszner and Strahan's results do provide important clues as to why particular legislation passes at times and not at other times. For example, technological and economic shocks reduced the market share of small banks, the traditional beneficiaries of branching restrictions, which weakened their ability to block interstate branching reform. Their results thus suggest how to think about getting desirable regulatory reforms passed. If legislation is designed to dissipate the efforts of different private interests against each other using a "divide and conquer" strategy, these private interests are less likely to support narrow special interest legislation. This research thus suggests how economists can increase the political sophistication of their recommendations (i.e., how to skin the cat) to address the interests of different constituencies to make passage of welfare-improving legislation more likely.

\subsection{Where Should Bank Supervision be Done?}

Countries have made different choices about which government agencies are responsible for prudential supervision. Some countries like Argentina have bank supervision housed entirely inside the central bank. Others completely separate the monetary policy function and bank supervision function and give no supervisory role to the central bank. In the United States, the Federal Reserve does have a supervisory function, but shares it with other supervisory agencies at both the state and federal level.

In their paper, Joe Peek, Eric Rosengren and Geoffrey Tootell focus on an economic 
consideration for where supervision should be done that has been largely neglected in discussions about the design of the bank supervisory structure. Peek, Rosengren and Tootell show that there is a synergy between the supervisory and monetary policy functions, because information provided by bank examinations helps increase the accuracy of macroeconomic forecasts. Forecast accuracy of macroeconomic variables is essential to the monetary policy function because successful monetary policy is necessarily forward looking. Without accurate macro forecasts, monetary policymakers cannot know what values are the right ones to set for their policy instruments in order to achieve their goals. Peek, Rosengren and Tootell examine recent proposals in the United States for redesign of the bank supervisory system to see which of them gives the Federal Reserve the most useful information to improve macroeconomic forecasts relevant for monetary policy. They find that supervisory information from banks regulated by the Federal Reserve does improve macroeconomic forecasts of inflation and unemployment rates, but the greatest improvement comes from supervisory information on state-chartered banks that are typically supervised by the Federal Deposit Insurance Corporation (FDIC) or the Office of the Comptroller of the Currency (OCC). Thus Peek, Rosengren and Tootell's results might indicate that there is a potential cost to monetary policy if the central bank is excluded from participation in bank supervision, or even if the central bank is limited to supervising only the largest institutions.

The discussant, Ben Bernanke, raises the issue, which the Peek, Rosengren and Tootell paper is well aware of, that the most important consideration for where banking supervision should be done is not the improvement of monetary policy, but rather whether it promotes financial stability. He argues that bank supervision needs to be in the central bank in order to facilitate the central bank's lender-of-last-resort role. The Peek, Rosengren and Tootell paper sparked a lively discussion by the participants in the conference as to whether bank supervision should be inside the central bank, and there were many different views expressed on this issue.

An interesting issue raised by the Peek, Rosengren and Tootell paper is whether there are other ways for information to be shared by supervisory agencies, so that even if the central bank is not engaged in supervision it still gets the supervisory information that helps it improve the accuracy of its macroeconomic forecasts. Peek, Rosengren and Tootell suggest that "hands on" experience is necessary for the central bank to get the supervisory information it needs, a 
view echoed by Alan Greenspan in a quote cited in the Peek, Rosengren and Tootell paper. However, different institutional design of the relationship of the central bank with outside supervisory agencies may enable the central bank to get the information it needs, and this could be an interesting topic for future research.

\subsection{Banking Supervision and the Aggregate Economy}

Although banking supervision's primary purpose is to promote financial stability, by affecting bank lending it can also have ancillary effects on the aggregate economy. There is a large literature which suggests that the capital crunch that occurred in the late 1980s and early 1990s, due to loan losses which ate away bank capital and increased capital requirements, led to a credit crunch in which bank lending was restricted, with a negative effect on aggregate demand that slowed down the economy. ${ }^{9}$ The paper by Berger, Kyle and Scalise provides further evidence on the potential impact of prudential supervision on the aggregate economy by looking at whether supervisors changed their toughness during the credit crunch period, 1989-92, and in the 1993-98 period following, and whether these changes in toughness had an impact on aggregate bank lending.

As mentioned earlier, Berger, Kyle and Scalise do find some limited evidence that bank examiners became tougher in the 1989-92 period, but they found even stronger evidence that bank examiners eased up on banks during the 1993-98 period. They then find that these changes in supervisory toughness did affect bank lending behavior in the expected direction, with increased toughness leading to a contraction in lending and easing to expansion in lending. However, all of these measured results were rather small, suggesting that changes in supervisory toughness do not explain much of the dramatic changes in aggregate bank lending over the last decade or so. This evidence suggests that changes in supervisory toughness can have effects on the aggregate economy which might be important information for monetary policy makers who may want to adjust policy instruments because of these effects. However, as pointed out by the discussant, Stephen Cecchetti, the measured effects that Berger, Kyle and

\footnotetext{
${ }^{9}$ For example, see Bernanke and Lown (1991), Federal Reserve Bank of New York (1993), Berger and Udell (1994), Berger, Kashyap and Scalise (1995), Hancock, Laing and Wilcox (1995) and Peek and Rosengren (1995).
} 
Scalise find may in part reflect changes in the general economic environment, rather than changes in supervisory toughness per se. It should also be noted that because Berger, Kyle and Scalise do not look at all the channels through which changes in bank balance sheets affect the aggregate economy, their results do not rule out large potential cyclical effects from capital requirements on the aggregate economy.

\section{6. \\ Conclusions}

This paper has tried to show that getting prudential supervision right is extremely important to the health of the economy. The papers following in this volume have many interesting things to say about some of key issues in prudential supervision. They will hopefully provide results which can help guide policymakers to enhance the effectiveness of prudential supervision in the future. 


\section{References}

Akerlof, George. 1970. "The Market for Lemons: Quality Uncertainty and the Market Mechanism." Quarterly Journal of Economics (84): 488-500.

Ang, James S. and Terry Richardson, 1994. "The Underwriting Experience of Commercial

Bank Affiliates Prior to the Glass-Steagall Act: A Re-examination of Evidence for Passage of the Act." Journal of Banking and Finance 18 (2): 351-95.

Basel Committee on Banking Supervision. 1999. A New Capital Adequacy Framework. Basel, Switzerland: Bank for International Settlements.

Beatty, Randolph P., R. Thompson, and Michael Vetsuypens. 1998. "Issuance Costs and Regulatory Change in the Investment Banking Industry." Southern Methodist University, mimeo.

Benston, George, 1990. The Separation of Commercial and Investment Banking: The GlassSteagall Act Revisited and Reconsidered. Oxford: Oxford University Press.

Berger, Allen N., and Timothy H. Hannan. 1998. "The Efficiency Cost of Market Power in the Banking Industry: A Test of the Quiet Life" and Related Hypotheses." Review of Economics and Statistics 80 (3): 454-65.

Berger, Allen N., Anil K. Kashyap and Joseph M. Scalise. 1995. "The Transformation of the U.S. Banking Industry: What a Long Strange Trip It's Been." Brookings Papers on Economic Activity, 2: 55-201.

Berger, Allen N., and Gregory F. Udell. 1994. "Did Risk-Based Capital Requirements Allocate Bank Credit and Cause a 'Credit Crunch' in the United States?" Journal of Money, Credit and Banking, 26: 585-628.

Berger, Allen N. and Gregory F. Udell. 1995. "Relationship Lending and Lines of Credit in Small Firm Finance." Journal of Business 68 (July): 351-382.

Bernanke, Ben S. 1983. "Non-Monetary Effects of the Financial Crisis in the Propagation of the Great Depression", American Economic Review, Vol. 73: 257-76.

Bernanke, Ben S. and Cara Lown. 1991. "The Credit Crunch." Brookings Papers on Economic Activity, 2: 205-39. 
Boyd, John and Mark Gertler M. 1993. "U.S. Commercial Banking: Trends, Cycles and Policy." NBER Macroeconomics Annual 1993: 319-368.

Corsetti, Giorgio., Pesenti, Paolo and Noriel Roubini. 1998. "What Caused the Asian Currency and Financial Crisis? Part I and II," NBER Working Papers, No. 6833 and 6844.

Diamond, Douglas W.. 1984. "Financial Intermediation and Delegated Monitoring." Review of Economic Studies 51 (3): 393-414.

Edwards, Franklin and Frederic S. Mishkin. 1995. "The Decline of Traditional Banking: Implications for Financial Stability and Regulatory Policy." Federal Reserve Bank of New York Economic Policy Review 1 (3): 27-45.

Federal Reserve Bank of New York. 1993. "The Role of the Credit Slowdown in the Recent Recession." Federal Reserve Bank of New York Quarterly Review, 18 (1).

Flannery, Mark J. 1998. "Using Market Information in Prudential Bank Supervision: A Review of the U.S. Empirical Evidence." Journal of Money, Credit and Banking (August): 273305.

Friedman, Milton and Anna J. Schwartz. 1963. A Monetary History of the United States, 18671960. Princeton, N.J.: Princeton University Press.

Gande, Amar, Manju Puri, Anthony Saunders, and Ingo Walter. 1997. "Bank Underwriting of Debt Securities: Modern Evidence." Review of Economic Studies 10 (4): 1175-1202.

Gande, Amar, Manju Puri, and Anthony Saunders. 1999. "Bank Entry, Competition and the Market for Corporate Securities Underwriting." Journal of Financial Economics 54(2): forthcoming.

Hancock, D., Laing, A.J. and J.A. Wilcox. 1995. "Bank Capital Shocks: Dynamic Effects on Securities, Loans and Capital." Journal of Banking and Finance 19 (3-4): 661-77.

Kane Edward J. 1989. The S\&L Insurance Mess: How Did it Happen? Washington, D.C.: Urban Institute Press.

Kashyap, Anil, Rajan, Raghuram, and Jeremy Stein. 1999, "Banks as Liquidity Providers: An Explanation for the Coexistence of Lending and Deposit-Taking." NBER Working Paper, 6962.

Keeley, Michael C. 1990. "Deposit Insurance, Risk and Market Power in Banking," American Economic Review 80(5): 1183-1200. 
Kroszner, Randall S. and Raghuram G. Rajan. 1994. "Is the Glass-Steagall Act Justified? A Study of the U.S. Experience with Universal Banking Before 1933." American Economic Review 84 (4): 810-832.

Kroszner, Randall S. and Raghuram G. Rajan. 1997. "Organizational Structure and Credibility: Evidence from Commercial Bank Securities Activities Before the Glass-Steagall Act." Journal of Monetary Economics 39: 475-516.

Marcus, Alan. 1984. "Deregulation and Bank Financial Policy," Journal of Banking and Finance.

Mishkin, Frederic S. 1991. "Asymmetric Information and Financial Crises: A Historical Perspective. In Financial Markets and Financial Crises, edited by R. Glenn Hubbard. Chicago: University of Chicago Press: 69-108.

Mishkin, Frederic S. 1996. "Understanding Financial Crises: A Developing Country Perspective," Annual World Bank Conference on Development Economics: 1996: 29-62.

Mishkin, Frederic S. 1997. "Evaluating FDICIA." In FDICIA: Bank Reform Five Years Later and Five Years Ahead, edited by George Kaufman. Greenwich, Conn: JAI Press: 17-33.

Mishkin, Frederic S. 1999. "Lessons from the Asian Crisis," Journal of International Money and Finance, Vol 18, NO. 4 (August): 709-723.

Nakamura, Leonard I. 1993. "Commercial Bank Information: Implications for the Structure

of Banking." in Structural Change in Banking, edited by M. Klausner and L.J. White. New York: Irwin: 131-160.

Peek, Joseph and Eric S. Rosengren. 1995. "Bank Regulation and the Credit Crunch." Journal of Banking and Finance, 19 (2-4): 679:92.

Petersen, Mitchell A. and Raghuram G. Rajan. 1994. "The Benefits of Firm-Creditor Relationships: Evidence from Small Business Data." Journal of Finance 49 (1): 3-37.

Puri, Manju. 1994. "The Long-Term Default Performance of Bank Underwritten Security Issues." Journal of Banking and Finance 18: 397-418.

Rojas-Suarez, Liliana and Steven Weisbrod. 1996. "Building Stability in Latin American Financial Markets." In Securing Stability and Growth in Latin America, edited by Ricardo Hausman and Helmut Reisen. Paris: OECD Development Center and Inter-American 
Development Bank.

Stiglitz, Joseph E., and Andrew Weiss. 1983. "Incentive Effects of Terminations: Applications to Credit and Labor markets." American Economic Review (73): 912-27. 